\title{
International migration as a driver of political and social change: evidence from Morocco
}

\section{Michele Tuccio $^{1}$ - Jackline Wahba ${ }^{2}$ - Bachir Hamdouch ${ }^{3}$}

Received: 11 May 2017 / Accepted: 3 April 2019 / Published online: 18 May 2019

(C) The Author(s) 2019

\begin{abstract}
This paper focuses on the impact of international migration on the transfer of political and social norms. Exploiting recent and unique data on Morocco, this paper explores whether households with return and current migrants bear different political preferences and behaviours than non-migrant families. Once controlling for the double selection into emigration and return migration, the findings suggest that having a returnee in the household increases the demand for political and social change. This result is driven by returnees mostly from Western European countries, who were exposed to more democratic norms in the destination. However, we find a negative impact of having a current migrant on the willingness of the left-behind households to change. This result is driven by migrants to non-Western countries, where the quality of political and social institutions is lower. Our results are robust to also controlling for destination selectivity.
\end{abstract}

Keywords International migration · Political change - Transfer of norms · Social remittances $\cdot$ Morocco

JEL Classification D72 · F22 - O15 - O55

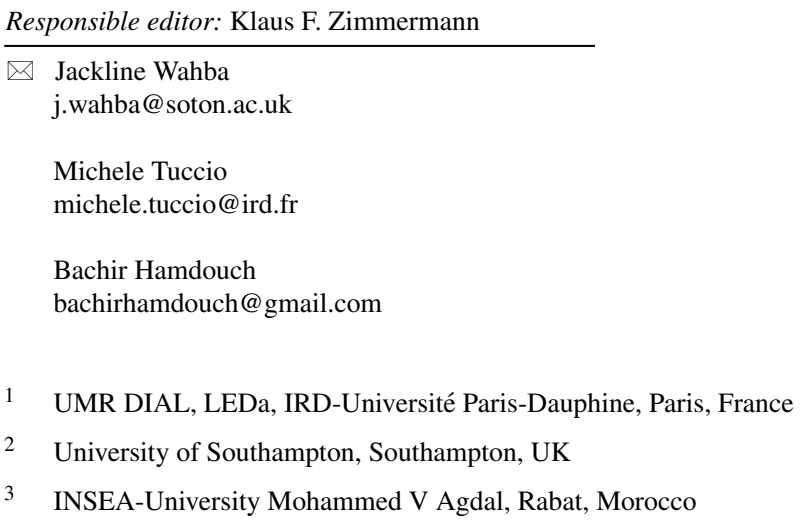




\section{Introduction}

In the early 2010s, the Arab world saw a revolutionary wave of protests spreading throughout the region, sparked by dissatisfaction with the rule of governments, as well as human rights' violations and political corruption. By 2014, civil uprisings had spread across the Arab countries, most notably in Tunisia, Egypt, Libya, Yemen and Syria. Everybody was asking for one thing: change.

A salient feature of all those troubled Arab countries-with the exception of Libya-is that they have high emigration rates. Hence, an interesting question given this context is whether international migration is a driver of political and social change. More precisely, are returnees more likely to ask for change than nonmigrants? Do current migrants catalyse the diffusion of new values? This paper explores the migration-induced transfer of political and social norms and its linkages with political outcomes. It examines whether international migrants contribute to a change in preferences and behaviours by channelling modern political norms from destination countries to Morocco (a high emigration country). In addition, it investigates the importance of destinations in the transmission of social remittances, in particular, in the adoption of liberal values, since newly incorporated norms vary according to the level of democracy and political accountability in host countries.

We focus on a North African country-Morocco-which is one of the world's leading emigration countries, with an estimated 4.5 million Moroccans residing abroad in 2014, approximately $13 \%$ of the population. In particular, more than 3 million Moroccans are living in Europe making them one of the largest migrant communities in Europe (Hamdouch and Wahba 2015). At the same time, Morocco has been seen instigating calls for political change over the last few years. Inspired by the wave of protests in the neighbouring countries, demonstrators rallied during 2011-2012 to fight government corruption, a lack of civil rights and absence of legitimate elections.

The main aim of our analysis is to test the potential causal link of these two key features of Morocco: that is, whether migration shapes political attitudes. Empirical studies on the impact of international migration on social remittances and in particular on political norms are recent and growing (see Section 2 for a comprehensive review of the existing literature). However, a large segment of those studies do not directly observe how migration affects the political views of migrants or their households as they tend to measure both migration and social remittances at a local level (see for example Pfutze 2012 and Chauvet and Mercier 2014). In contrast, we examine the direct effect of international migration on political attitudes and preferences and identify the underlying mechanisms behind the potential impact of migration. Moreover, the previous literature often adopted proxies of political beliefs, such as institutional quality and democracy, which do not entirely capture individuals' preferences nor measure the likelihood of migrants acting as a catalyst of political change. We exploit unique information on migration experiences and political and social norms at the individual level, allowing a direct estimation of the impact of migration on the preference for change.

Our second contribution to the literature is in addressing several selections, and in particular selection into the destination. To the best of our knowledge, we are the first study simultaneously tackling all three possible selections: selection into emigration, 
selection into return migration and, most importantly, selection into the destination. ${ }^{1}$ We address the double selection into emigration and into return migration, since both migrants and returnees are not random samples of the population, but they may be self-selected on the basis of observed and unobserved characteristics. Importantly, we also address an additional source of selectivity that is self-sorting into destination countries. Indeed, this may be a remarkable source of bias in the previous literature on the migration-induced transfer of norms. We tackle endogeneity and selectivity issues by adopting a multi-equation mixed system, where both emigration selectivity, selection into return migration and destination sorting are taken into account.

We also compare the different impacts of returnees and diaspora on political and social change. Whilst the vast majority of previous studies have focused on a single category of migrants (exceptions are Batista and Vicente 2011 and Barsbai et al. 2017), only an overall analysis of all types of international migration can give a clear picture of the mechanisms behind the migration-induced transfer of norms. We hence compare the attitudes of returnee households to the ones of non-migrants, as well as the norms of the left-behind family members of current migrants to those of nonmigrants. In addition, we also examine the heterogeneity of Moroccan emigrants' destinations in order to corroborate the findings on the importance of host countries. Variation in the destinations of Moroccans to Western and Arab countries allows us to estimate opposite preferences for political and social change according to the institutions in place abroad. Finally, to show the potential impact of migration on actual outcomes as opposed to on just attitudes and preferences, albeit at the locality level, we show how a greater exposure to return migration is correlated with higher turnout rates to the 2011 parliamentary elections.

Our estimates suggest that, once controlling for selections, return migration boosts the demand for political and social change in Morocco. Results are driven by returnees from the West, which have been exposed to more democratic norms in the destination. In contrast, households with a current migrant are on average less likely to ask for change than non-migrant families, driven by migrants to non-Western countries. The findings are robust to different specifications, sub-samples and techniques. This suggests that social remittances can not only be positive but also negative depending on the country of destination where the migrant lived. To confirm the importance of our findings, we also present results based on the 2011 World Value Survey and the 2004 Census, showing that returnees affect general political attitudes in the region where they live. In addition, we show that return migration is associated with outcomes such as the turnout for elections, as we find that regions with larger returnee shares were more likely to have greater turnout to the 2011 political elections.

The remainder of the paper is structured as follows: After a review of the existing literature on the migration-induced transfer of political norms in Section 2, Section 3 introduces stylized facts on the migration patterns in Morocco, as well as provides a description of the data used in our main analysis. Section 4 presents our methodology and econo-

\footnotetext{
${ }^{1}$ Tuccio and Wahba (2018) study the effect of return migration in Jordan on women empowerment and decision making but they do not address the destination selection as they focus only on return migrants who went to Arab countries.
} 
metric approach. Estimation results on return and current migration are discussed in Section 5, whilst Section 6 presents extensions to the analysis. Section 6 concludes.

\section{Related literature}

Given their importance for economic performance, there has been growing interest in the determinants of political institutions in the last years (see for example Barro 1999 and Acemoglu and Robinson 2005). A specific focus of that literature has been on what triggers political change and in particular on the impact of economic downturns. For instance, Brückner and Ciccone (2011) show that negative shocks measured by rainfall can lead to democratic improvement, whilst Chaney (2013) uses historical data to show that economic crises increase the probability of the collapse of autocratic regimes by temporarily altering the balance of political power. Others have examined several alternative factors behind political transitions such as the role of mass media in affecting political outcomes (Enikolopov et al. 2011) or the role of riots and clashes (Aidt and Franck 2015). Focusing on the Arab World, Campante and Chor (2012) argue that the recent political changes observed since 2011 are due to educational expansion and unrewarding labour market opportunities.

Closer to our interest is the relationship between international migration and political institutions. Focusing on the quality of institutions and using panel data for bilateral student flows from 1950 to 2003, the seminal work of Spilimbergo (2009) provides evidence that foreign educated individuals promote domestic democracy, but only if the level of democracy in destination countries is high. After the pioneering contribution of Spilimbergo (2009), a new strand of the economic literature started to look at the migration-induced transfer of norms or social remittances.

At the macro level, there have been a few studies looking at the impact of emigration on the quality of institutions, such as Beine and Sekkat (2013), who find a positive and significant effect of international migration on the change in institutions, and Docquier et al. (2016), who confirm these findings when restricting the focus to developing countries.

At the micro level, instead, several studies exploited electoral data. Looking at the 2000-2002 Mexican municipal elections, Pfutze (2012) estimates that a one percentage point increase in the proportion of migrant households in a municipality boosts the probability that a party in opposition to the former state party wins the elections by more than half a percent. Chauvet and Mercier (2014) use electoral data from Mali in order to explore the link between return migration and political outcomes. They find that localities with greater shares of returnees from non-African countries are more likely to have higher electoral participation rates. Similarly, Barsbai et al. (2017) provide evidence that Moldovan municipalities sending migrants to democratic countries experience an increase in political support for more democratic and liberal parties in elections. However, none of these studies observe neither individual migration experience nor individual voting behaviour. ${ }^{2}$ In an attempt to address the

\footnotetext{
${ }^{2}$ In order to explain their district-level results of a political spillover from emigration, Barsbai et al. (2017) draw on individual-level data from the Moldovan Political Barometer and exit polls, but without dealing with the selectivity and endogeneity issues.
} 
endogeneity issues arising from the reverse causality between emigration and political opinions, Chauvet et al. (2016) adopt a multi-sited exit-poll survey conducted during the 2013 Malian elections in Paris, Abidjan and Bamako together with an instrumental variable strategy. They find that Malians in France have more democratic views than both migrants in Cote d'Ivoire and non-migrants, but they deal with a highly selected sample to start with, namely Malian voters in Mali, France and Cote d'Ivoire, and do not show the transfer of norms to the left-behind families. In a similar vein, also Karakoc et al. (2017) use original survey data from Egypt to show that individuals with household members who had emigrated to the Gulf were more likely to vote for Islamist parties in the last election. However, no attempt is made to disentangle migrant selectivity and endogeneity issues.

A growing strand of the literature looked specifically at the impact of emigration on corruption back home. Batista and Vicente (2011) customize a survey of perceived corruption in public services in Cape Verde, where they additionally ask respondents to mail a pre-stamped postcard if they wanted the anonymous results of the survey to be made publicly available in the media. Interestingly, localities with high international emigration prevalence had higher demand for political accountability. Ivlevs and King (2017) exploit the Gallup Balkan Monitor to show that the emigration of family members and close friends reduces bribery and the acceptability of corruption among those staying behind in the source countries. In a similar vein, Höckel et al. (2018) find that parental emigration is correlated with a reduction in informal payments to school teachers.

It is worth stressing that-in addition to the diffusion of political norms at the core of this paper-the economic literature has also focused on the migration-induced transfer of other types of norms, such as fertility (Beine et al. 2013; Bertoli and Marchetta 2015), gender norms (Tuccio and Wahba 2018; Diabate and MespléSomps 2019), civic-engagement and pro-social behaviour (Nikolova et al. 2017). Overall, the existing evidence points at a correlation between the values and opinions of host countries and those of the left-behind families of migrants abroad. In spite of a clear nexus between the two, there is still large scope for further corroborating analysis on the matter, especially because of the strong bias that endogeneity and selectivity issues carry when trying to assess the transfer of social norms through migration. Not least as the literature has not attempted to disentangle the destination choice selectivity which could be confounding previous findings.

\section{The case of Morocco}

\subsection{Migration in Morocco}

Over the last decades, Morocco has become one of the world's leading emigration countries. Over 4 million Moroccans are estimated to be living abroad. Almost three million Moroccans live in Europe. The largest concentration of Moroccans living abroad is in France. In the Netherlands, Moroccans are the third largest group and in Belgium Moroccans are the largest group of non-EU immigrants. Yet, in terms of absolute numbers of Moroccans, Spain hosts the second largest Moroccan diaspora 
followed by Italy. The remainder of Moroccans are dispersed in the USA and Canada among other countries, whilst about $5 \%$ are in other Arab countries. ${ }^{3}$

Seasonal and circular migration patterns within national borders have characterized Morocco's pre-colonial population history for centuries. However, the great migration boom has exploded only in the 1960s, when the European economies were rapidly expanding in the aftermath of World War II and were in need of unskilled labour for their mining, industry and construction sectors. Until the mid of the 1970s economic and oil crisis, both Moroccan emigrants and host countries were expecting migration to be temporary in nature, and return migration was a key feature of the Moroccan diaspora. On average, Moroccans resided for 7 to 10 years in Europe and then returned home (Hamdouch and Wahba 2015), but the following period of economic stagnation led European governments to close their borders to new migrants, and many Moroccans decided not to return but stay in their host countries. It was mainly through family reunification programme and irregular migration that the Moroccan diaspora in Europe managed to grow steadily.

A direct consequence of the restriction of immigration policies in northwest Europe was a diversification in migration patterns. Many new Moroccan immigrants shifted from classic destinations, such as France, Belgium, Germany and Netherlands, to the southern countries of Spain and Italy, where undocumented trespassing or overstaying was easier. Similarly, a significant number of Moroccans migrated to Libya and oil-producing Gulf countries, as well as to the USA and French-speaking Canada.

Although return migration is relatively less important in Morocco than in other Middle Eastern and North African neighbouring countries, it is certainly a growing feature, especially over the last few years, when the financial crisis lowered economic opportunities everywhere, and in particular in those countries where Moroccan immigration is important, such as Spain and Italy. However, national estimates of Moroccan returnees are out-dated. The only national data available are those of the 2004 population census, which indicates an average of 33,100 returnees per year. ${ }^{4}$ As mentioned by de Haas (2014), migration data from European destinations suggest that about a quarter of Moroccans who migrated between 1981 and 2009 returned to Morocco. Also, the share of returnees fluctuates with the business cycle in Europe.

As a result of the lack of data, research on return migration in Morocco is rather limited. A few studies though have examined returnees' occupational choice and entrepreneurship. Using detailed survey data collected by the Centre for Studies and Demographic Research (CERED) at the High Commission of Planning (HCP) in 2003-2004 on return migrants in two main regions of Morocco (Great Casablanca and Souss-Massa-Draa), Hamdouch and Wahba (2015) examine the determinants of entrepreneurial behaviour among return migrants, controlling for the potential endogeneity of migration duration, and the potential endogenous impact of having invested overseas. Another exception is Gubert and Nordman (2011) who, using the

\footnotetext{
${ }^{3}$ See Khachani (2012) and de Haas (2014) for a survey on migration trends in Morocco.

${ }^{4}$ This estimate is eventually an underestimation of the real extent of return migration, since it does not take into account undocumented and illegal migration.
} 
DReMM data, explore the occupational status of returnees in Morocco and in the whole Maghreb.

To our knowledge, this is the first paper examining the impact of both current and return migration on political and social attitudes in Morocco. Although Morocco has not seen the turmoil caused by the Arab Spring in other parts of the Arab world, intense pro-democracy demonstrations were put in place in 2011 by the "February 20 Movement" against the political, social and economic conditions. As a result, a new constitution aimed at improving democracy and the rule of law was adopted by referendum in July 2011 .

\subsection{Data and descriptive statistics}

The analysis of this paper is based on a new and unique dataset, the "Investigation on the Impact of International Migration on Development in Morocco" (IIIMD), produced by the Association Migration Internationale with the support of the International Organization for Migration and the Ministry for the Moroccans Residing Abroad and Emigration. The survey was conducted in August-October 2013 for about 1200 households. Since the investigation is national in scope, it covers the entire national territory and is a representative sample of all private households in Morocco (including those composed of foreign individuals), representing the 16 regions of the country in the two areas of residence (urban and rural). The observed units consist of both households having no migrant member, households with one or more migrants currently abroad, households with one or more returnees and households with at least one immigrant.

The sampling frame used in IIIMD is based on the repeated national demographic survey sample (ENDPR) carried out by the Office of the High Commissioner in 2009-2010 to ensure the representativeness of the sample (households with international migrants, households with immigrants, households without migrants etc.). The sample of the repeated national demographic survey is itself based on the master sample set up by the Statistics Directorate following the 2004 General Population and Housing Census (RGPH) to meet the needs of household surveys representing the entire national territory, and consequently all regions and social strata of the country.

The IIIMD sampling was multi-stage. ${ }^{5}$ In a first step, 62 primary units were randomly selected from the ENDPR survey proportionally to the size of the units in terms of density of the various types of migrants (returnee and current). Then, two secondary units were randomly drawn in each primary unit (with equal probabilities). Lastly, 10 households have been selected with equal probabilities in each secondary unit. Sampling weights are provided and are used in the analysis.

The dataset contains unique features that are key for our analysis. Firstly, it includes questions on non-migrant, current and return migrant households, which can be exploited to compare different types of migration experiences, and also to control for the double selection into emigration and return migration. Specifically, the observed units consist of both native-born households with no migrant (243),

\footnotetext{
${ }^{5}$ See Hamdouch and Mghari (2014) for more details about the IIIMD survey methodology.
} 
Table 1 Characteristics of migrants

\begin{tabular}{lll}
\hline & Return migrant & Current migrant \\
\hline Destination & & \\
Spain & 0.147 & 0.208 \\
France & 0.342 & 0.303 \\
Italy & 0.284 & 0.227 \\
Other European countries & 0.080 & 0.158 \\
USA & 0.009 & 0.046 \\
Canada & 0.013 & 0.020 \\
Arab countries & 0.111 & 0.033 \\
African countries & 0.004 & 0.002 \\
Other countries & 0.009 & 0.003 \\
& & \\
Educational level & & 0.110 \\
No education & 0.413 & 0.219 \\
Primary education & 0.173 & 0.252 \\
College & 0.200 & 0.287 \\
Secondary education & 0.153 & 0.125 \\
Post-secondary education & 0.060 & 11.51 \\
Duration of migration & & \\
Years & 11.32 & \\
\hline & &
\end{tabular}

Data source: IIIMD 2013

native-born households with one or more family members currently abroad (658), native-born households with one or more returnee family members (228) and foreignborn (non-Moroccans) households (105). In each household, only one individual is interviewed, but information about the whole household is collected. In the majority of cases, the head of household, or failing that the spouse, is the respondent. ${ }^{6}$

Table 1 compares destination and education levels of current and return migrants. Host countries are similar for both types of migrants. Interestingly, France, Italy or Spain is the destination of around three quarters of migrants. On average, return and current migrants have spent the same time abroad (11 years), which is consistent with the aforementioned stylized fact that nowadays Moroccans tend to stay longer at the destination, due to restrictive immigration policies which would impede them from returning to the host country if they leave. On the other hand, educational attainment differs greatly between current and return migrants. Returnees are less educated, with

\footnotetext{
${ }^{6}$ In our econometric analysis, we also control for whether the respondent is the head of household or not.
} 
$41 \%$ uneducated individuals, whilst only $11 \%$ of current migrants have not undertaken formal education. Conversely, over $40 \%$ of current migrants hold a secondary or higher degree, a proportion which is halved for returnees.

A second distinctive feature of the IIIMD is the inclusion of questions on the willingness to change the social and political landscapes, which are a direct measure of individuals' attitudes and beliefs. For instance, we exploit a set of variables included in the IIIMD on political and social norms, administered to both households with a returnee, families with a current migrant abroad and non-migrant households. Our analysis is based on five questions on the willingness to change the traditional Moroccan society and politics: (1) "Are you happy about how Morocco is administered?" (2) "I think we should defend the traditional lifestyle in Morocco". (3) "We need to make more effort in order to treat men and women equally". (4) "We need to make more effort in order to treat everybody equally". (5) "I think people should be more involved in the decision-making process".

We adopt several dimensionality reduction techniques in order to aggregate the five aforementioned variables into a composite index of political and social norms. Nevertheless, we also run specifications with each single indicator as the dependent variable to show that our results are not driven by the construction of the composite index. In our benchmark analysis, we use principal components analysis (PCA), which has been extensively used to construct multidimensional and composite indexes (Filmer and Pritchett 2001). Its clear advantage is to measure the group of weights that explains the largest variation in the original variables. The robustness of our composite indicator is tested by using two additional weighting techniques. Firstly, we adopt multiple correspondence analysis (MCA), which has been often preferred to analyze qualitative, categorical and binary variables (Asselin 2002). Secondly, we make use of equal weights that have largely been used for their simplicity and apparent objectivity (Tuccio and Wahba 2018).

The proposed index of political and social change is constructed such that it takes values from 0 , corresponding to preference for no change, to 1 , meaning complete preference for change, and it is given by:

$$
Y_{i}^{j}=A_{i 1} W_{1}^{j}+A_{i 2} W_{2}^{j}+\ldots+A_{i q} W_{q}^{j}
$$

where $Y_{i}^{j}$ is the value of composite index $Y$ for individual $i$ using the weighting technique $j$ (namely, PCA, MCA and Equal weights), $A_{i q}$ is the answer of individual $i$ to question $q$ and $W_{q}^{j}$ is the weight obtained using the $j$ methodology applied to question $q .^{7}$

The analysis of this paper is restricted to individuals who are working age (1565 years old) at the time of the survey, in order to exclude those individuals whose political norms may be very different due to their young or old age. Moreover, we exclude from the analysis migrants who left the country for political issues, as well

\footnotetext{
${ }^{7}$ Table 13 in the Appendix lists the five variables that are used to construct the Political and Social Change Index and the respective weights using PCA, MCA and equal weights. Larger weights imply greater preference for political and social change.
} 
Table 2 Characteristics of respondents from households with no migrants, returnees and current migrants

\begin{tabular}{|c|c|c|c|}
\hline & Without migrant & With returnee & With current \\
\hline \multicolumn{4}{|l|}{ Political and social change (\%) } \\
\hline Political administration & 0.24 & 0.32 & 0.29 \\
\hline Civil engagement & 0.92 & $0.86^{*}$ & 0.89 \\
\hline Traditional lifestyle & 0.06 & 0.04 & 0.04 \\
\hline Gender equality & 0.89 & 0.89 & 0.89 \\
\hline Social cohesion & 0.94 & 0.95 & 0.94 \\
\hline Composite index (PCA) & 0.61 & 0.61 & 0.61 \\
\hline Composite index (MCA) & 0.8 & 0.79 & 0.79 \\
\hline Composite index (equal weights) & 0.61 & 0.61 & 0.61 \\
\hline \multicolumn{4}{|l|}{ Educational level (\%) } \\
\hline No education & 0.35 & 0.40 & 0.40 \\
\hline Primary education & 0.23 & 0.18 & 0.20 \\
\hline College & 0.15 & 0.18 & 0.12 \\
\hline Secondary education & 0.18 & 0.19 & 0.20 \\
\hline Superior education & 0.09 & 0.06 & 0.09 \\
\hline \multicolumn{4}{|l|}{ Individual characteristics } \\
\hline Female & 0.29 & $0.19^{*}$ & $0.43 * * *$ \\
\hline Age & 48.5 & $54.44 * * *$ & $53.79 * * *$ \\
\hline Married & 0.81 & 0.79 & $0.69 * * *$ \\
\hline Rural areas & 0.15 & 0.16 & 0.12 \\
\hline Metropolis & 0.23 & 0.19 & 0.22 \\
\hline Employment status & 0.54 & 0.45 & $0.34 * * *$ \\
\hline Head of household & 0.73 & 0.74 & 0.69 \\
\hline Accommodation owner & 0.63 & $0.89 * * *$ & $0.80^{* * *}$ \\
\hline$N$ & 216 & 225 & 658 \\
\hline
\end{tabular}

$t$ test for different means, where the control group is always those individuals with no migrant in the household. $* * *, * *$ and $*$ represent $1 \%, 5 \%$ and $10 \%$ significance levels, respectively. Data source: IIIMD, 2013

as returnees who came back to Morocco for political reasons, since they would bias our estimates. ${ }^{8}$ Finally, immigrants are not included as non-migrant households since they may carry a different set of political and social norms than natives.

Table 2 compares the characteristics of individuals from households with a returnee, individuals from a current migrant household and individuals from non-

\footnotetext{
${ }^{8}$ Note that all our estimates exclude individuals who self-reported having left or returned to Morocco for political reasons as they are only a very small share (less than $1 \%$ ) of our sample, but would bias our estimates. We have though, as a robustness check, included those migrants and found that all our results are robust.
} 
migrant households. It appears clear that, without controlling for selectivity issues, individuals in our sample do not differ along most of characteristics. In particular, our outcomes of interest (i.e. the five proxies of political and social change, as well as the three different composite indicators using PCA, MCA and equal weights) do not suggest specific differences among migration experiences. Econometric techniques are therefore required in order to better understand the impact of international migration on political norms.

\section{Methodology}

\subsection{Empirical strategy}

We first focus on return migration. We are interested in understanding whether returnee households differ in their political norms from non-migrant households. We therefore model two interrelated decisions: the propensity to want change (2) and the probability of being a returnee (3). The preference for change in the political and social landscapes is proxied by the constructed composite indicator $Y_{i}$.

$$
Y_{i}=\alpha_{0}+\alpha_{1} R_{i}+\alpha_{2} X_{i}+\alpha_{3} F_{r}+\epsilon_{i}
$$

In Eq. $2, Y_{i}$ is the level of political and social change desired by individual $i$, which can take any value between 0 and 1 , where 0 means no change and 1 implies complete change. $R_{i}$ is the return migration variable, a dummy equal to 1 if the individual has at least a returnee member within the household. $X_{i}$ is a vector of individual characteristics, including age, educational attainment, marital status, employment status and living in a rural area or in a metropolis (3 biggest Moroccan cities: Casablanca, Fez, Rabat-Sale), being the head of the household and a dummy for owing the accommodation, a proxy for wealth. ${ }^{9}$ Fixed effects at the regional level are absorbed by $F_{r}$, whilst $\epsilon_{i}$ is a zero-mean error term.

The return migration decision is instead denoted by $R$ and is observed only when the latent variable measuring the gains from being a return migrant $\left(R^{*}\right)$ is positive.

$$
\left\{\begin{array}{l}
R=1 \text { if } R^{*}>0, M>0 \\
R=0 \text { otherwise }
\end{array}\right.
$$

However, we need to introduce a third decision, since return migration is only measured if the individual has emigrated. Hence, $R$ is only observed if an individual has emigrated i.e. $M>0$. The emigration decision $(M)$ is observed when the latent variable measuring the gains from migration $\left(M^{*}\right)$ is positive.

$$
\left\{\begin{array}{l}
M=1 \text { if } M^{*}>0 \\
M=0 \text { otherwise }
\end{array}\right.
$$

\footnotetext{
${ }^{9}$ As a robustness check, we excluded educational attainment, employment status and home ownership as controls that could potentially be endogeneous, and all our results are robust.
} 
We therefore estimate a multi-equation mixed system, where the three decisions above are estimated simultaneously using a conditional mixed process (CMP) estimator (Wahba 2015). CMP fits a seemingly unrelated regressions (SUR) framework, in which regressors seem unrelated as no endogenous component appears as explanatory variable in the other equations, although their errors can be correlated (Roodman 2011). In CMP, equations may vary in sample sizes: selection equations will be modelled for the full data set, whilst the dependent variable of interest in equation (2) will be modelled for the subset with complete observations. ${ }^{10}$

\subsection{Identification}

Although our data allow us to control for observable variables affecting the selection of migrants, unobservables may still induce those who have migrated to be self-selected on the basis of some latent characteristics. If both emigrants and return migrants are not a random sample of the Moroccan population, estimates would be biased. The correct identification of the full structural model requires two valid exclusion restrictions for the emigration and return decisions. For the emigration decision, we construct a proxy for the attractiveness of the foreign labour market in each year. Specifically, our measure is given by:

$$
A_{t}=\max \left(G_{j t}-G_{m t}\right) W_{j}^{1990}
$$

$A_{t}$ is the most attractive foreign labour market at time $t . G_{j t}$ is the GDP per capita growth rate of destination $j$ at time $t$, whilst $G_{m t}$ is the growth rate of Morocco at time $t .{ }^{11}$ This measure of foreign attractiveness is weighted by the size of the diaspora given the importance not only of economic factors, but also of social networks in emigration. Weights $W_{j}^{1990}$ are constructed as follows: using data from Özden et al. (2011), we take the share of Moroccan stocks, in each destination country $j$, in the total Moroccan migrant population in 1990. We adopt $A_{t}$ for when the individual was 23 years old, which is the average year of finishing education, assuming that this is when individuals enter in the labour market. However, we also check the robustness of our results using an alternative age, between 25 and 30 years of age, see Table 14 in the Appendix. The attractiveness of foreign countries relative to Morocco in the past when the individual was 23 should have no bearing on their opinion at the time of survey in 2013 when the average age of non-migrant is 49 and 54 years of age in the case of return migrants. Yet, as Giuliano and Spilimbergo (2013) show, individuals

\footnotetext{
${ }^{10}$ See Roodman (2011) p. 161: “CMP is flexible in another way: models can vary by observation. In other words, they can be conditioned on the data. CMP stands for conditional mixed process. Thus within the CMP universe is the Heckman selection model, in which sample selection (represented by a dummy variable) is modelled in parallel with a dependent variable of interest: selection is modelled for the full dataset, and the dependent variable is modelled for the subset that has complete observations."

${ }^{11}$ To make sure that the relative economic attractiveness of foreign destinations to Morocco is not correlated with political preferences, we run an additional robustness check where the exclusion restriction for the probability of emigration is the absolute (rather than relative) attractiveness of foreign labour markets. Results remain robust and are available upon request.
} 
who experienced a recession when young have different political beliefs when old. Thus, as a robustness check, we test whether the relative attractiveness of foreign countries has any effect on the political views of members of households with no migration experience. As expected, we find no effect (see Table 15 in the Appendix).

For the return migration decision, we construct a measure of exogenous shocks that might have induced Moroccan emigrants to return home-i.e. we use a dummy variable equal to 1 if the migrant was exposed to conflict or unfavourable change in legislation at the time of migration. There are several potential shocks. Firstly, the explosion of the Gulf War in 1990 has led to a great out-migration of Moroccan migrants from oil-producing Gulf states. Secondly, in 2000, a xenophobic uprising exploded in Libya, triggered by the rising unemployment of natives, inconsistency in migration policy and an increasing presence of foreign workers (Migration Policy Centre 2013). Unrest led to the deaths of hundreds of foreigners, encouraging many immigrants working in Libya to return to their origin countries. Thirdly, in 2004, film-director Theodoor Van Gogh was murdered by Moroccan Mohammed Bouyeri in Amsterdam. The murder sparked a violent storm of outrage and grief throughout the Netherlands, which may have lead some Moroccan immigrants to return home.

In our shock variable, we also include two new pieces of legislation in destination countries where many Moroccans were present. These laws were particularly restrictive against undocumented migrants, and consequently they provoked an outflow of Moroccans. In total, $16 \%$ of our sample of returnees came back to Morocco due to these two shocks. Firstly, in 2006, France approved a new immigration law that toughened up restrictions on immigrants who do not have skills and qualifications targeted by the French government as important to France (Chou and Baygert 2007). Previously, illegal immigrants in France could obtain documents to ensure legal status if they could demonstrate a stay in-country of 10 years or more, whilst the new law scrapped these regulations. Moreover, the government planned approximately 26,000 deportations in that year only, due to the high volume of undocumented immigrants. Similarly, a new immigration law was passed in Italy in 2009 that made illegal immigration an official crime, and as such helping or housing undocumented migrants resulted in a prosecutable offense. Employment of irregular migrants became punishable with up to 5 years of imprisonment. Teachers in schools were also compelled to report undocumented children to officials.

It is worth stressing that, whilst these shocks increased the propensity to return home in a given year, they did not affect the probability of emigration given the multiple available destinations. Figure 1 in the Appendix shows graphically that our chosen shocks are not associated with a decrease in the magnitude of emigration from Morocco. In addition, negative past shocks in destination countries are clearly not directly correlated with Moroccans' political and social norms in 2013, as opinions are measured back home on issues such as equality or on local matters such as traditional lifestyle in Morocco.

We therefore estimate a system of three equations as follows:

$$
\left\{\begin{array}{l}
Y_{i}=\alpha_{0}+\alpha_{1} R_{i}+\alpha_{2} X_{i}+\alpha_{3} F_{r}+\epsilon_{i} \\
R_{k}=\beta_{0}+\beta_{1} S_{k}+\beta_{2} C_{k}+\beta_{3} F_{r}+n_{k} \\
M_{k}=\gamma_{0}+\gamma_{1} A_{t}+\gamma_{2} Z_{k}+\gamma_{3} F_{r}+\mu_{k}
\end{array}\right.
$$


In the return migration equation, $R_{k}$ is the linear probability of individual $k$ being a return migrant, conditional on being an emigrant, and $S_{k}$ represents the shock variable, constructed as previously explained. Note that individuals $i$ in the first equation and $k$ in the selection equations may coincide or not. In particular, $i=k$ if the survey respondent $i$ is directly the family member who migrated and returned. Conversely, $i \neq k$ if respondent $i$ is not the returnee $k$ himself. We also check the robustness of our results to whether the respondent is the returnee or a member of their household in the next section. Two-thirds of the respondents in returnee households are the returnees themselves. Importantly, we have only one individual per household in the survey. ${ }^{12}$ Controls $C_{k}$ are the characteristics of the returnee. In the emigration equation, $M_{k}$ is the linear probability being an emigrant, whilst $A_{t}$ is the attractiveness of the foreign labour market. Controls $Z_{k}$ include the characteristics, such as age, sex and education, of the migrant and the household left behind. ${ }^{13}$

\section{Estimation results}

\subsection{Households of return migrants and change}

We first look at the impact of having a returnee in the household on the preference for political and social change. The main outcome variable in Table 3 is the composite indicator of preference for change as previously constructed through principal component analysis (PCA). In line with the descriptive statistics of Table 2, no effect is found using a simple OLS estimator (column 1). However, controlling for selection into return migration and emigration leads to a strongly significant impact of return migration on the demand for political and social change (columns 2 and 3). This emphasizes that migrants are not randomly chosen among the Moroccan population, but are selected on the basis of some observed and unobserved characteristics.

It is worth noting that both the shock variable and the measure of attractiveness of the foreign labour market (instrumental variables) are significant. The shock dummy is a good predictor of the probability of being a returnee, whilst our measure of attractiveness of the foreign labour market also has a positive and significant impact on the likelihood of emigrating in a given year. Looking at the correlations among equations, the results suggest a negative selection of both current and return migrants. Return migrants are on average more unskilled, engaged in agriculture and poorer compared with non-migrants which could explain their negative selectivity with respect to liberal views (see Hamdouch and Wahba 2015). However, those who returned to Morocco are positively selected among the migrants' pool. Return migration behaviours, therefore, accentuate the selection that characterized the initial emigration flows, as discussed by Borjas and Bratsberg (1996).

\footnotetext{
${ }^{12}$ Note that in additional regressions, we also include a dummy if the survey respondent is the returnee himself/herself as further control, and results are robust. Tables available upon request. Due to small sample sizes, we cannot instead run the regressions using two complete separate samples.

${ }^{13}$ We also cluster the standard errors at the municipality level and find consistent results.
} 
Table 3 Return migration and the preference for political and social change

(1)

$-0.004$

(0.26)

Probability of return migration

Shock

Probability of emigration

Attractiveness

(2)

(3)

Political and social change

Return migration

$(33.68)^{* * *}$

0.059

0.093

$(2.72)^{* * *}$

$(2.52)^{* * *}$

0.792

$(27.28)^{* * *}$

0.050

$(2.84)^{* * *}$

sigma_1

$-1.163$

$-1.160$

$(31.30)^{* * * *}$

(30.99)***

sigma_2

rho_12

$-0.181$

$-0.981$

(29.59)***

(2.79)***

$-0.212$

(2.93)***

$-0.169$

(1.78)*

0.292

$(6.46)^{* * *}$

441

$* * *, * *$ and $*$ represent $1 \%, 5 \%$ and $10 \%$ significance levels, respectively. All specifications are weighted by the sampling weights provided in the dataset, with robust standard errors ( $t$ statistics in parentheses). The selection equations are based on full sample of 1524 observations. Data source: IIIMD 2013

To test the robustness of our findings, Table 4 shows results using two alternative outcome variables: the composite index of political and social change aggregated through multiple correspondence analysis (columns 1,2 and 3) and using equal weights (columns 4,5 and 6). We can safely reject the eventuality that previous estimates were driven by the weighting technique used to construct the composite indicator, since return migration still bears a positive and significant effect on preference for change.

We conduct several tests to check the robustness of our results to our exclusion restrictions. First, we use two alternative exclusion restrictions for the selection into emigration equation. We have constructed the first alternative measure as follows: for each year, we picked the maximum attractiveness of the foreign labour markets in only the main destinations in each region, that is France for Europe, Canada for North America and Libya for MENA region. ${ }^{14}$ The exclusion restriction appears to be a strong predictor of the probability of emigration, leaving positive and significant the

\footnotetext{
${ }^{14}$ On the contrary, the former exclusion restriction considered the whole world.
} 
Table 4 Return migration and the preference for change using different weighting techniques

\begin{tabular}{|c|c|c|c|c|c|c|}
\hline & $\begin{array}{l}\text { (1) } \\
\text { MCA }\end{array}$ & $\begin{array}{l}\text { (2) } \\
\text { MCA }\end{array}$ & $\begin{array}{l}\text { (3) } \\
\text { MCA }\end{array}$ & $\begin{array}{l}\text { (4) } \\
\text { Equal }\end{array}$ & $\begin{array}{l}\text { (5) } \\
\text { Equal }\end{array}$ & $\begin{array}{l}\text { (6) } \\
\text { Equal }\end{array}$ \\
\hline \multicolumn{7}{|c|}{ Political and social change } \\
\hline Return migration & $\begin{array}{l}0.004 \\
(0.21)\end{array}$ & $\begin{array}{l}0.050 \\
(1.88)^{*}\end{array}$ & $\begin{array}{l}0.072 \\
(2.24)^{* *}\end{array}$ & $\begin{array}{l}0.005 \\
(0.33)\end{array}$ & $\begin{array}{l}0.055 \\
(2.20)^{* *}\end{array}$ & $\begin{array}{l}0.079 \\
(2.60) * * *\end{array}$ \\
\hline \multicolumn{7}{|c|}{ Probability of return migration } \\
\hline Shock & & $\begin{array}{l}0.833 \\
(33.68)^{* * *}\end{array}$ & $\begin{array}{l}0.792 \\
(27.30)^{* * *}\end{array}$ & & $\begin{array}{l}0.833 \\
(33.68)^{* * * *}\end{array}$ & $\begin{array}{l}0.792 \\
(27.29) * * *\end{array}$ \\
\hline \multicolumn{7}{|c|}{ Probability of emigration } \\
\hline Attractiveness & & & $\begin{array}{l}0.050 \\
(2.88) * * *\end{array}$ & & & $\begin{array}{l}0.050 \\
(2.87) * * *\end{array}$ \\
\hline sigma_1 & & $\begin{array}{l}-1.163 \\
(31.30)^{* * *}\end{array}$ & $\begin{array}{l}-1.160 \\
(30.99)^{* * *}\end{array}$ & & $\begin{array}{l}-1.163 \\
(31.30)^{* * *}\end{array}$ & $\begin{array}{l}-1.160 \\
(30.99)^{* * *}\end{array}$ \\
\hline sigma_2 & & & $\begin{array}{l}-0.981 \\
(29.59)^{* * *}\end{array}$ & & & $\begin{array}{l}-0.981 \\
(29.60)^{* * *}\end{array}$ \\
\hline rho_12 & & $\begin{array}{l}-0.123 \\
(1.87)^{*}\end{array}$ & $\begin{array}{l}-0.143 \\
(1.99)^{* *}\end{array}$ & & $\begin{array}{l}-0.146 \\
(2.20)^{* *}\end{array}$ & $\begin{array}{l}-0.171 \\
(2.38)^{* *}\end{array}$ \\
\hline rho_13 & & & $\begin{array}{l}-0.106 \\
(1.38)\end{array}$ & & & $\begin{array}{l}-0.132 \\
(1.66)^{*}\end{array}$ \\
\hline rho_23 & & & $\begin{array}{l}0.292 \\
(6.45) * * *\end{array}$ & & & $\begin{array}{l}0.292 \\
(6.47)^{* * * *}\end{array}$ \\
\hline$N$ & 441 & 441 & 441 & 441 & 441 & 441 \\
\hline
\end{tabular}

$* * *, * *$ and $*$ represent $1 \%, 5 \%$ and $10 \%$ significance levels, respectively. All specifications are weighted by the sampling weights provided in the dataset, with robust standard errors ( $t$ statistics in parentheses). The selection equations are based on full sample of 1524 observations. Data source: IIIMD 2013

effect of return migration on attitudes towards change (Table 16). As second alternative exclusion restriction, we used the GDP per capita growth rate of Morocco at the age of when the individual entered the job market (i.e. 23 years old for non-migrant and the year of migration for migrants). This exclusion restriction should capture the push factor rather than the pull factor for emigration. Table 17 confirms the consistency of our previous findings. As an additional robustness check, we use a different exclusion restriction also to address the return migration selection, exploiting conflict data from the Correlates of War Project. ${ }^{15}$ In particular, we focus on all destination countries of Moroccans and construct a dummy equal to 1 if the migrant has been exposed to any militarised disputes abroad. Only current migrants abroad at the time of the conflict could be at risk. Our findings are robust (see Table 18 in the Appendix).

Since results may be driven by the use of composite indicators (regardless of the weighting technique applied), Table 5 shows specifications where the outcome of interest has been replaced by the single sub-indexes. In particular, columns 1, 2 and 3 present results using the dummy variable "I am not happy with how Morocco is run/administered" (proxy for political norms), whilst columns 4,5 and 6 use the

\footnotetext{
${ }^{15}$ All data are publicly available at: www.correlatesofwar.org
} 
Table 5 Return migration and the preference for change using single variables

\begin{tabular}{|c|c|c|c|c|c|c|}
\hline & (1) & (2) & (3) & (4) & (5) & (6) \\
\hline & \multicolumn{3}{|c|}{ Good administration } & \multicolumn{3}{|c|}{ Gender equality } \\
\hline \multicolumn{7}{|c|}{ Political and social change } \\
\hline Return migration & $\begin{array}{l}0.060 \\
(1.48)\end{array}$ & $\begin{array}{l}0.126 \\
(1.91)^{*}\end{array}$ & $\begin{array}{l}0.176 \\
(1.86)^{*}\end{array}$ & $\begin{array}{l}0.060 \\
(1.71)^{*}\end{array}$ & $\begin{array}{l}0.069 \\
(1.57)\end{array}$ & $\begin{array}{l}0.099 \\
(1.75)^{*}\end{array}$ \\
\hline \multicolumn{7}{|c|}{ Probability of return migration } \\
\hline Shock & & $\begin{array}{l}0.833 \\
(33.68)^{* * *}\end{array}$ & $\begin{array}{l}0.792 \\
(27.29)^{* * *}\end{array}$ & & $\begin{array}{l}0.833 \\
(33.68)^{* * *}\end{array}$ & $\begin{array}{l}0.792 \\
(27.38)^{* * *}\end{array}$ \\
\hline \multicolumn{7}{|c|}{ Probability of emigration } \\
\hline Attractiveness & & & $\begin{array}{l}0.050 \\
(2.87)^{* * *}\end{array}$ & & & $\begin{array}{l}0.050 \\
(2.86)^{* * *}\end{array}$ \\
\hline sigma_1 & & $\begin{array}{l}-1.163 \\
(31.30)^{* * *}\end{array}$ & $\begin{array}{l}-1.160 \\
(31.01)^{* * *}\end{array}$ & & $\begin{array}{l}-1.163 \\
(31.30)^{* * *}\end{array}$ & $\begin{array}{l}-1.160 \\
(31.01)^{* * *}\end{array}$ \\
\hline sigma_2 & & & $\begin{array}{l}-0.980 \\
(29.57)^{* * *}\end{array}$ & & & $\begin{array}{l}-0.981 \\
(29.67)^{* * *}\end{array}$ \\
\hline rho_12 & & $\begin{array}{l}-0.066 \\
(1.06)\end{array}$ & $\begin{array}{l}-0.084 \\
(1.23)\end{array}$ & & $\begin{array}{l}-0.050 \\
(1.00)\end{array}$ & $\begin{array}{l}-0.064 \\
(1.18)\end{array}$ \\
\hline rho_13 & & & $\begin{array}{l}-0.092 \\
(0.91)\end{array}$ & & & $\begin{array}{l}-0.071 \\
(0.96)\end{array}$ \\
\hline rho_23 & & & $\begin{array}{l}0.292 \\
(6.47)^{* * *}\end{array}$ & & & $\begin{array}{l}0.290 \\
(6.44)^{* * *}\end{array}$ \\
\hline$N$ & 441 & 441 & 441 & 441 & 441 & 441 \\
\hline
\end{tabular}

***, $* *$ and $*$ represent $1 \%, 5 \%$ and $10 \%$ significance levels, respectively. Columns (1-3) refer to Good administration. Columns (4-6) refer to Gender Equality. All specifications are weighted by the sampling weights provided in the dataset, with robust standard errors ( $t$ statistics in parentheses). The selection equations are based on full sample of 1524 observations. Data source: IIIMD 2013

dummy "We need to make more effort in order to treat men and women equally" (proxy for social norms). Findings are robust to this additional test too.

In order to understand the reasons behind the positive sign of the coefficient of return migration, and also to clarify whether migrants do actually transfer norms from host to home countries, we further disaggregate results by destination. By distinguishing between migrants from Western (Europe, USA and Canada) and nonWestern (Arab) countries, we expect that returnees from more democratic countries should drive our results, as they have assimilated more equal and democratic values whilst living abroad. Table 6 confirms our hypothesis: the findings are driven by returnees from Western countries, whilst the coefficient for non-Western returnees is not statistically significant which could potentially be due to the small sample size. Column 1 of Table 6 shows that Western countries' returnees are more likely to want change relative to non-migrants and returnees from non-Western countries. Comparing only returnee households, those with returnees from the West to families 
Table 6 Return migration by destination and the preference for change

\begin{tabular}{|c|c|c|c|c|}
\hline & (1) & (2) & (3) & (4) \\
\hline & $\begin{array}{l}\text { Unconditional } \\
\text { West }\end{array}$ & $\begin{array}{l}\text { Unconditional } \\
\text { Non-West }\end{array}$ & $\begin{array}{l}\text { Conditional } \\
\text { West }\end{array}$ & $\begin{array}{l}\text { Conditional } \\
\text { West }\end{array}$ \\
\hline \multicolumn{5}{|c|}{ Political and social change } \\
\hline Return migration & $\begin{array}{l}0.074 \\
(2.71)^{* * *}\end{array}$ & $\begin{array}{l}-0.044 \\
(1.15)\end{array}$ & $\begin{array}{l}0.067 \\
(2.05)^{* *}\end{array}$ & $\begin{array}{l}0.068 \\
(2.08)^{* *}\end{array}$ \\
\hline \multicolumn{5}{|c|}{ Probability of return migration } \\
\hline Shock & $\begin{array}{l}0.796 \\
(28.20)^{* * * *}\end{array}$ & $\begin{array}{l}0.798 \\
(28.23)^{* * * *}\end{array}$ & $\begin{array}{l}0.792 \\
(27.41)^{* * * *}\end{array}$ & $\begin{array}{l}0.792 \\
(27.45)^{* * *}\end{array}$ \\
\hline \multicolumn{5}{|c|}{ Probability of emigration } \\
\hline Attractiveness & $\begin{array}{l}0.050 \\
(2.85)^{* * *}\end{array}$ & $\begin{array}{l}0.051 \\
(2.89)^{* * *}\end{array}$ & $\begin{array}{l}0.051 \\
(2.91)^{* * *}\end{array}$ & $\begin{array}{l}0.051 \\
(2.91)^{* * *}\end{array}$ \\
\hline sigma_1 & $\begin{array}{l}-1.160 \\
(31.02)^{* * * *}\end{array}$ & $\begin{array}{l}-1.160 \\
(31.03)^{* * *}\end{array}$ & $\begin{array}{l}-1.160 \\
(30.97)^{* * *}\end{array}$ & $\begin{array}{l}-1.160 \\
(30.98)^{* * *}\end{array}$ \\
\hline sigma_2 & $\begin{array}{l}-0.981 \\
(29.62)^{* * * *}\end{array}$ & $\begin{array}{l}-0.981 \\
(29.63)^{* * * *}\end{array}$ & $\begin{array}{l}-0.981 \\
(29.59)^{* * *}\end{array}$ & $\begin{array}{l}-0.980 \\
(29.60)^{* * *}\end{array}$ \\
\hline rho_12 & $\begin{array}{l}-0.170 \\
(2.90)^{* * *}\end{array}$ & $\begin{array}{l}-0.068 \\
(1.43)\end{array}$ & $\begin{array}{l}-0.243 \\
(2.92)^{* * *}\end{array}$ & $\begin{array}{l}-0.248 \\
(2.96)^{* * *}\end{array}$ \\
\hline rho_13 & $\begin{array}{l}-0.117 \\
(1.43)\end{array}$ & $\begin{array}{l}0.029 \\
(0.47)\end{array}$ & $\begin{array}{l}-0.375 \\
(1.47)\end{array}$ & $\begin{array}{l}-0.341 \\
(1.38)\end{array}$ \\
\hline rho_23 & $\begin{array}{l}0.290 \\
(6.47)^{* * *}\end{array}$ & $\begin{array}{l}0.290 \\
(6.50)^{* * *}\end{array}$ & $\begin{array}{l}0.291 \\
(6.47)^{* * *}\end{array}$ & $\begin{array}{l}0.293 \\
(6.52) * * *\end{array}$ \\
\hline$N$ & 441 & 441 & 225 & 225 \\
\hline
\end{tabular}

$* * *, * *$ and $*$ represent $1 \%, 5 \%$ and $10 \%$ significance levels, respectively. Columns 3 and 4 are conditional on return migration. All specifications are weighted by the sampling weights provided in the dataset, with robust standard errors ( $t$ statistics in parentheses). The selection equations are based on full sample of 1524 observations. Data source: IIIMD 2013

with returnees from non-Western countries, suggest that the former are more likely to demand change than the latter (column 3). This result is in line with the findings of de Haas and Fokkema (2010) (p. 251), who, using semi-structured interviews in the Todgha valley, note that "exposure to European media and public discourse is likely to have influenced migrants' attitudes towards Moroccan lifestyle and bureaucracy. Also, migrants might attempt to present themselves as more modern and superior by dissociating themselves from Moroccan authorities and society".

A further concern might be related to the selectivity/exogeneity of the migration destination. In fact, it can be argued that more open-minded individuals may prefer to migrate in the first place to the democratic Western countries. If this is the case, then the effect previously found would not be due to a migration-induced transfer of norms, but rather to a selection bias. In Table 19 in the Appendix, we show evidence suggesting that our sample is not remarkably affected by this issue. Indeed, we exploit three variables included in the IIIMD database in order to proxy for openmindedness ("Your main reason to emigrate was to improve your lifestyle"; "Overall, would you say you are happy to have lived abroad?"; "Would you like to migrate 
again abroad?" ). We then run an additional migration equation where the dependent variable is a dummy equal to 1 if the returnee lived in the West, whilst it is 0 if he/she lived in a non-Western country. Importantly, we control for the three aforementioned proxies of open-mindedness (both separately in columns 1 to 3 , simultaneously in column 4, and aggregated in a composite indicator through PCA in column 5) and show that being more open-minded is not a major driver of migration towards more democratic Western countries. We then use the composite index of open-mindedness as an additional control in column 4 of Table 6: the results are robust, suggesting that, if anything, selection into the destination is not a major concern in our sample. We will come back to the issue of the self-sorting into the destination below, where we will test the robustness of our main findings to the addition of a further selection equation. We also check the robustness of our results if the respondent is not the returnee himself/herself but another member of their households. The results are robust (see Table 20 in the Appendix).

\subsection{Households of current migrants and change}

We now turn to the impact of having a current migrant $E_{i}$ in the household on the preference for political and social change (Table 7). We estimate the following model:

$$
\left\{\begin{array}{l}
Y_{i}=\alpha_{0}+\alpha_{1} E_{i}+\alpha_{2} X_{i}+\alpha_{3} F_{r}+\epsilon_{i} \\
E_{k}=\gamma_{0}+\gamma_{1} A_{t}+\gamma_{2} Z_{k}+\gamma_{3} F_{r}+\mu_{k}
\end{array}\right.
$$

As before, in the political change equation, $Y_{i}$ is the level of political and social change desired by individual $i$, which can take any value between 0 (no change) and 1 (complete change). In the emigration equation, $E_{k}$ is the probability of being an emigrant.

Table 7 Current migration and the preference for political and social change

\begin{tabular}{|c|c|c|c|c|c|c|c|}
\hline & (1) & (2) & (3) & (4) & $(5)$ & (6) & (7) \\
\hline & PCA & PCA & MCA & Equal & PCA & PCA & PCA \\
\hline \multicolumn{8}{|c|}{ Political and social change } \\
\hline Current migration & $\begin{array}{l}-0.036 \\
(1.67)^{*}\end{array}$ & $\begin{array}{l}6-0.140 \\
(2.66)^{* * *}\end{array}$ & $\begin{array}{l}-0.158 \\
(2.58)^{* * *}\end{array}$ & $\begin{array}{l}-0.084 \\
(1.88)^{*}\end{array}$ & $\begin{array}{l}-0.134 \\
(2.20)^{* *}\end{array}$ & $\begin{array}{l}-0.183 \\
(2.61)^{* * *}\end{array}$ & $\begin{array}{l}-0.179 \\
(2.49)^{* *}\end{array}$ \\
\hline \multicolumn{8}{|c|}{ Probability of emigration } \\
\hline Attractiveness & & $\begin{array}{l}0.073 \\
(3.33)^{* * *}\end{array}$ & $\begin{array}{l}0.070 \\
(3.20)^{* * *}\end{array}$ & $\begin{array}{l}0.071 \\
(3.10)^{* * * *}\end{array}$ & $\begin{array}{l}0.058 \\
(2.77)^{* * *}\end{array}$ & $\begin{array}{l}0.089 \\
(3.47)^{* * *}\end{array}$ & $\begin{array}{l}0.102 \\
(3.52)^{* * * *}\end{array}$ \\
\hline sigma_1 & & $\begin{array}{l}-0.908 \\
(28.55) * * *\end{array}$ & $\begin{array}{l}-0.908 \\
(28.55)^{* * *}\end{array}$ & $\begin{array}{l}-0.908 \\
(28.53)^{* * *}\end{array}$ & $\begin{array}{l}-0.954 \\
*(26.11) * * *\end{array}$ & $\begin{array}{l}-0.881 \\
(22.60)^{* * *}\end{array}$ & $\begin{array}{l}-0.879 \\
(18.64)^{* * *}\end{array}$ \\
\hline rho_12 & & $\begin{array}{l}0.364 \\
(2.37)^{* *}\end{array}$ & $\begin{array}{l}0.381 \\
(2.74)^{* * *}\end{array}$ & $\begin{array}{l}0.224 \\
(1.69)^{*}\end{array}$ & $\begin{array}{l}0.303 \\
(1.75)^{*}\end{array}$ & $\begin{array}{l}0.517 \\
(2.62)^{* * *}\end{array}$ & $\begin{array}{l}0.527 \\
(2.50)^{* *}\end{array}$ \\
\hline$N$ & 448 & 448 & 448 & 448 & 510 & 300 & 228 \\
\hline
\end{tabular}

$* * *, * *$ and $*$ represent $1 \%, 5 \%$ and $10 \%$ significance levels, respectively. All specifications are weighted by the sampling weights provided in the dataset, with robust standard errors ( $t$ statistics in parentheses). The selection equations are based on full sample of 732 observations. Data source: IIIMD 2013 
Caution is required when estimating this model. Emigration from Morocco is largely male dominated, and consequently survey respondents in households with a current emigrant abroad are more likely to be left-behind women compared with non-migrant families where the male head is usually the respondent. As a matter of fact, our data show that, whilst no woman has been interviewed among non-migrant families, one out of three respondents with a current migrant is a female. A clear bias may arise if men and women carry different social norms. Therefore, in order to have comparable treatment and control groups, columns 1 to 4 of Table 7 exclude females from the estimation sample, although we show the robustness of the results to including women in columns 5 and 6.

Remarkably, left-behind households of current migrants have lower demand for political and social change across all specifications. ${ }^{16}$ Column 2 presents our benchmark results, controlling for selection into emigration and using the composite index constructed through PCA. Results are however robust to the use of MCA (column 3) and equal weights (column 4). It may be the case that current migrants are mostly the former heads of the household, who migrated abroad in order to provide for the left-behind family. If this was correct, comparing non-migrant households to respondents with a current migrant may again bias our estimates, since we might be comparing nonmigrant heads of the family with sons or elderly of migrant heads, who may bear different social norms. For this reason, column 5 includes only heads of the household from the analysis. In column 6 , we also test the robustness of our findings to focusing only on employed people, as we may want to restrict the analysis to individuals comparable in terms of their labour market status. Finally, column 7 is most parsimonious specification, where we focus only on male and employed heads of the household.

Regardless of the specification, results suggest a negative impact of current migration on political and social change, and according to our theoretical predictions, this should be due to a stream of less democratic norms from destination countries. We therefore test this hypothesis by disaggregating between Western and non-Western migrants. Findings in Table 8 do confirm a transfer of norms and show that the negative coefficient of current migration is driven by migrants from non-Western countries, which indeed have lower institutional quality and democracy levels than Morocco. When comparing migrants currently in the West to migrants in non-Western countries, we notice that, conditional on migration, individuals in Europe and North America are more likely to transfer political change than migrants in the Arab world (column 3).

\subsection{Destination selectivity}

Importantly, a still unexplored potential source of bias may be due to the selfselection process of migrants into destination countries. In fact, when deciding to emigrate, individuals may choose to move to specific locations according to unobservable (to the econometrician) characteristics or preferences. For instance, in the previous section and Table 19, we provided evidence that open-mindedness does not affect our results on return migration. In Table 9, we test the robustness of our

\footnotetext{
${ }^{16}$ As a robustness, we check for whether monetary remittances affect the left behind's political attitudes. All our results are not affected and are not driven by the receipt of monetary remittances.
} 
Table 8 Current migration by destination and the preference for change

\begin{tabular}{llll}
\hline & $(1)$ & $(2)$ & $(3)$ \\
& Unconditional & Unconditional & Conditional \\
& West & Non-West & West \\
\hline Political and social change & & & \\
Current migration & 0.008 & -0.095 & 0.092 \\
& $(0.16)$ & $(2.43)^{* * *}$ & $(2.61)^{* * *}$ \\
Probability of emigration & & & 0.059 \\
Attractiveness & 0.056 & 0.057 & $(2.78)^{* * *}$ \\
& $(2.59)^{* * *}$ & $(2.67)^{* * *}$ & -1.013 \\
sigma_1 & -1.013 & & $(31.47)^{* * *}$ \\
rho_12 & $(31.45)^{* * *}$ & -1.013 & 0.112 \\
$N$ & -0.068 & $(31.45)^{* * *}$ & $(0.45)$ \\
\hline
\end{tabular}

$* * *, * *$ and $*$ represent $1 \%, 5 \%$ and $10 \%$ significance levels, respectively. Column 3 is conditional on migration. All specifications are weighted by the sampling weights provided in the dataset, with robust standard errors ( $t$ statistics in parentheses). The selection equations are based on full sample of 732 observations. Data source: IIIMD 2013

main findings to the inclusion of an additional selection equation for self-sorting into Western/non-Western destinations conditional on migration. Specifically, our dependent variable is a dummy being 1 if migrants' destination is a Western country and 0 if it is a non-West (including Arab) country.

In order to estimate the model, however, a further exclusion restriction is needed which is not correlated with the probability of emigration in the first place nor the likelihood of return migration or social/political preferences in 2013. We hence construct the exclusion restriction as the ratio between GDP per capita growth in France and Libya (the two main destination countries in the two regions) as follows $F L_{t}=G_{\text {France }, t} / G_{\text {Libya,t }}$. Again, we use the average age of finishing education and entering the labour market (i.e. 23 years of age). This would clearly affect the location where the migrant chooses to move, but not the migration decision itself. It is worth noting that our previous exclusion restriction for the selection into emigration expressed in Eq. 5 would be violated if we include the selection into the destination equation in the simultaneous model. In fact, the most attractive foreign labour market would also affect the destination choice. Hence, we replace this exclusion restriction with the average attractiveness of the foreign market, as follows: $A V_{t}=\operatorname{mean}\left(G_{j t}-G_{m t}\right) W_{j}^{1990}$. We argue that $A V_{t}$ would capture more the push factor in determining migration: if Morocco is doing badly relative to on average all other countries, the individual decides to emigrate; otherwise, they would not emigrate. Also, $F L_{t}$ (the ratio between GDP per capita growth in France and Libya) when the individual first enters the labour market - at the age of 23 years-should not have any impact on the return decision nor on political and social preferences in 2013. 
Table 9 Selection into destination

(1)

(2)

Political and social change

Return migration 0.055

$(2.01)^{* *}$

Current migration

$(2.02)^{* *}$

Probability of return migration

Shock

$(31.24)^{* * * *}$

Probability of emigration

Attractiveness

$(5.63)^{* * *}$

$(5.74)^{* * *}$

Destination selection

Relative growth France/Libya

0.000

0.000

$(1.76)^{*}$

$(1.74)^{*}$

sigma_1

$-1.163$

$-1.045$

$(31.27)^{* * * *}$

$(26.47)^{* * * *}$

sigma_2

$-1.045$

$-1.152$

$(26.48)^{* * * *}$

$(8.56)^{* * * *}$

sigma_3

$-1.171$

$(8.18)^{* * * *}$

rho_12

$-0.181$

(2.70)***

rho_13

0.011

0.124

(0.16)

rho_14

0.122

$(1.66)^{*}$

rho_23

0.102

$(2.29)^{* *}$

(4.89)***

rho_24

$-0.011$

(0.17)

rho_34

1.179

$(4.32)^{* * * *}$

441

$* * *, * *$ and $*$ represent $1 \%, 5 \%$ and $10 \%$ significance levels, respectively. All specifications are weighted by the sampling weights provided in the dataset, with robust standard errors ( $t$ statistics in parentheses). The selection equations are based on full sample of 1524 observations. Data source: IIIMD 2013 
We estimate the following system to control for destination selectivity in the case of return migration, where $D_{k}$ is a dummy being 1 if the individual migrated to the West and 0 if he/she migrated to a non-West (including Arab) country.

$$
\left\{\begin{array}{l}
Y_{i}=\alpha_{0}+\alpha_{1} R_{i}+\alpha_{2} X_{i}+\alpha_{3} F_{r}+\epsilon_{i} \\
R_{k}=\beta_{0}+\beta_{1} S_{k}+\beta_{2} C_{k}+\beta_{3} F_{r}+n_{k} \\
D_{k}=\theta_{0}+\theta_{1} F L_{t}+\theta_{2} I_{k}+\theta_{3} F_{r}+\epsilon_{k} \\
M_{k}=\gamma_{0}+\gamma_{1} A V_{t}+\gamma_{2} Z_{k}+\gamma_{3} F_{r}+\mu_{k}
\end{array}\right.
$$

Similarly in the case of current migrants, we add the destination selection equation as follows:

$$
\left\{\begin{array}{l}
Y_{i}=\alpha_{0}+\alpha_{1} E_{i}+\alpha_{2} X_{i}+\alpha_{3} F_{r}+\epsilon_{i} \\
D_{k}=\theta_{0}+\theta_{1} F L_{t}+\theta_{2} I_{k}+\theta_{3} F_{r}+\epsilon_{k} \\
E_{k}=\gamma_{0}+\gamma_{1} A_{t}+\gamma_{2} Z_{k}+\gamma_{3} F_{r}+\mu_{k}
\end{array}\right.
$$

Estimates for both return migration (column 1) and the diaspora (column 2) show that self-selectivity into the destination does not alter our results. We find that return migration increases the demand for political and social change, but households of current migrants are less likely to want change-i.e. our findings remain robust to addressing this further potential selection. Indeed, we find that there is positive selection between choosing Western countries relative to non-Western countries and emigration. However, we find a negative significant correlation between return migration and Western destinations relative to non-Western countries, although it is not significant.

We finally calculate the predicted values of the impact of return and current migration on the preference for political and social change (Table 10). Results suggest that having a returnee family member increases preference for change by over $60 \%$. Confirming previous findings, this effect is due to returnees from Western countries, whilst returnees from non-Western countries have much closer preferences for change to those of non-migrant households. Focusing on households with a current migrant shows that on average the diaspora decreases the preference for change by 20 percentage points compared with respondents with no migration experience. This time, current migrants outside the Western world drive this result.

\section{Local effects of return migration}

In order to show the importance of our findings beyond individual attitudes and preferences, we explore whether social remittances, namely the new political norms that return migrants bring back home, expand beyond the household of origin to the local community. ${ }^{17}$

First, we use the 2011 World Values Survey (WVS) of Morocco and exploit two questions: "I do not have confidence in the government" and "I am interested into politics", which proxy for political preferences. We then utilise the most recent available population census carried out in 2004 to calculate the share of returnees among

\footnotetext{
${ }^{17}$ It is important to note that we use data at the locality level rather than at the individual level for this analysis as data on election participation as well as individual characteristics (including migration experience) is scarce.
} 
Table 10 Average predicted values

With migrant Without migrant $\quad$ Difference $(\%) \quad P$ value

$\begin{array}{lrlll}\text { Preference for change-return migration } & & & \\ \text { Whole sample } & 0.649 & 0.559 & 0.16 & 0.000 \\ \text { Returnees from the West } & 0.641 & 0.559 & 0.15 & 0.000 \\ \text { Returnees from the non-West } & 0.572 & 0.559 & 0.02 & 0.005\end{array}$

Preference for change—current migration

\begin{tabular}{lllll} 
Whole sample & 0.450 & 0.559 & -0.20 & 0.000 \\
Current migrants in the West & 0.557 & 0.559 & 0.00 & 0.000 \\
Current migrants in the non-West & 0.464 & 0.559 & -0.17 & 0.003 \\
\hline
\end{tabular}

$P$ value reports the results of a $t$ test of Ho: migration=non-migrants. Values are weighted by the sampling weights provided in the dataset. Data source: IIIMD 2013

the population of each of the 24 available sub-regions, which we then merge with the 2011 World Values Survey. The resulting dataset provides information on over 1100 individuals in Morocco on both political norms and the share of returnees in each sub-region. The following OLS regression is therefore estimated in order to test the existence of local effects of return migration:

$$
N_{i s}=\alpha_{0}+\alpha_{1} R_{s}+\alpha_{2} C_{i s}+\epsilon_{i s}
$$

where $N_{i s}$ is our proxy of political norms for individual $i$ living in sub-region $s$, and $R_{S}$ is the share of returnees in each of the 24 sub-regions. Controls $C_{i s}$ include sex and marital status dummies, age and age squared, number of children, educational attainment and working status as well as a dummy if individual $i$ works for the government.

Columns 1 (dependent variable: "I do not have confidence in the government") and 2 (dependent variable: "I am interested into politics") in Table 11 show the results of Eq. 10, which confirm that return migration affects political norms at the local level. Since the share of returnees may be endogenous, we also adopt a 2SLS estimation, where return migration is instrumented by the growth rate of returnees in each sub-region $\left(R G_{S}\right)$. In particular, data on the share of returnees by sub-region $\left(R_{S}\right)$ are calculated using the 2004 and the 1994 Moroccan census. The growth rate $R G_{s}$ of returnees in each sub-region $s$ is given by:

$$
R G_{s}=\frac{R_{s}^{2004}-R_{s}^{1994}}{R_{s}^{1994}}
$$

2SLS estimation in columns 3 and 4 of Table 11 emphasizes the validity of our instrument and the robustness of our findings: individuals in localities with a large share of return migrants are more likely than individuals in regions with fewer returnees to state that they do not have confidence in the government and that they are not interested in politics. 
Table 11 Local effects of return migration on political norms

Panel A: second stage

Share of returnees

Panel B: first stage

Return migration change

$\mathrm{R} 2$

$F$ Stat

$N$
(1)

3.776

$(1.68)^{*}$

7.787
$(2.58)^{* *}$
(2)

(3)

(4)

57.279

$(2.34)^{* *}$

26.109

(1.80)*

0.002

0.002

$(5.67)^{* * *}$

$(5.63)^{* * *}$

0.18

0.06

1073
32.11

1073
31.67

1155

Dep. var. in columns 1 and 3 is "I do not have confidence in the government", whilst dep. var. in columns 2 and 4 is "I am interested into politics". ***, ** and * represent $1 \%, 5 \%$ and $10 \%$ significance levels, respectively. All specifications are weighted by the sampling weights provided in the datasets, with robust standard errors ( $t$ statistics in parentheses). Data source: World Values Survey (WVS) 2011 ; Census 2004

Second, we want to examine whether political and social attitudes translate into actions and outcomes. We adopt the Round 5 of the AfroBarometer, a survey that measures public attitudes on economic, political and social matters in more than 30 African countries, carried out by the Institute for Justice and Reconciliation (IJR) in South Africa, the Ghana Center for Democratic Development, the Institute for Empirical Research in Political Economy in Benin, the Institute for Development Studies (IDS) at the University of Nairobi and the Department of Political Science at Michigan State University.

We focus on the survey for Morocco, which was undertaken in 2013 on 1200 individuals, and we exploit one question on the 2011 parliamentary election: "Did you vote in the last national election held in 2011?". It is worth noting that the demonstrations that exploded during the Arab spring led King Mohammed VI to establish an earlier election, to be held all around Morocco on November 25, 2011. By matching again the shares of returnees in each of the 60 localities from the 2004 Census with the AfroBarometer data, we are able to estimate the following specification:

$$
V_{i l}=\alpha_{0}+\alpha_{1} R_{l}+\alpha_{2} C_{i l}+\epsilon_{i l}
$$

where $V_{i l}$ is a dummy equal to 1 if individual $i$ has voted in the 2011 elections; $R_{l}$ is the share of returnees in locality $l$ where individual $i$ lives, and $C_{i l}$ are the controls, which include sex, age, age squared, rural dummy, education and employment status, as well as proxies for wealth, such as having a shelter's roof in cement and having the main source of water inside the house.

Indeed, the results in Table 12 show that individuals living in areas with higher concentration of returnees are more likely to have participated in the 2011 elections. Findings are robust to the inclusion of additional controls capturing regional characteristics, such as average educational attainment, employment rate and access to water and electricity (column 2), as well as instrumenting the share of returnees in a given locality by the growth rate of returnees in each locality $\left(R G_{l}\right)$, as 
Table 12 Local effects of return migration on political outcomes

(1)

Panel A: second stage

Share of returnees

Panel B: first stage

Return migration change

(2)

(3)

8.213

21.786

100.490

$(1.80)^{*}$

$(3.08)^{* * *}$

$(1.72)^{*}$

0.001

$(4.26)^{* * *}$

Regional controls

R2

No

0.11

Yes

0.13

$F$ Stat

1200

1200

$N$

Yes

18.17

1200

Dep. var. is a dummy being 1 if the individual has participated in the 2011 national elections. ***, ** and $*$ represent $1 \%, 5 \%$ and $10 \%$ significance levels, respectively. All specifications are weighted by the sampling weights provided in the datasets, with robust standard errors ( $t$ statistics in parentheses). Data source: AfroBarometer 2013; Census 2004

calculated above. In sum, using different databases, such as the 2011 World Value Survey, the 2013 AfroBarometer and the 1994/2004 Census, indicates that migration affects political preferences as well as behaviour.

\section{Conclusions}

Does international migration act as a driver of political and social change? We look at the interesting case of Morocco, a North African country that has become a major emigration hub to Europe and where there have been calls for political change over the last few years. We exploit a recent and unique dataset in order to test whether returnee households have different political behaviours and preferences than nonmigrants. The findings provide evidence that return migration has a positive impact on the preference for political and social change after controlling for the double selectivity of emigration and return migration. We further demonstrate that the positive impact of return migration is driven by returnees coming from Western countries, where they have acquired democratic political norms.

We also examine the impact of having a current migrant overseas on the attitudes of the left behind versus non-migrants. Interestingly, having a current migrant among the household members has an opposite and negative effect on the demand for political and social change, driven by migrants residing in Arab countries, where the level of political institutions and accountability is low. Importantly, we control for the destination selectivity and find that our results are not driven by the self-sorting of migrants across destinations.

Furthermore, in order to show that the impact of migration affects not only attitudes but also actions, we study electoral participation and find a positive and significant impact of the share of returnees in a given locality on the participation rate in the 2011 parliamentary elections. 
Overall, our findings suggest that international migration can be a driver of political and social change. However, the impact of host countries matters, as newly acquired norms and attitudes are not always "superior" to the norms at origin. This implies an eventual benefit for migration to Western countries, where the level of democracy and institutional quality is greater than in the rest of the world, and hence there is potential for positive social remittances from host to home countries. From a technical point of view, our paper shows that correcting for selection bias is of paramount importance when studying social remittances: not only are migrants a self-selected population, but also those among them who return home are not randomly selected. At the same time, migrants may choose a specific destination based on unobservable characteristics, and such destination selectivity may have biased the results of most of previous studies, given that it has often been neglected.

Acknowledgments We would like to thank Catia Batista, Michael Clemens, Corrado Giulietti, Hillel Rapoport and Mathis Wagner for helpful discussion. We are also grateful to Editor Klaus F. Zimmermann, the Managing Editor Madeline Zavodny, three anonymous reviewers and seminar participants at the World Bank, Centre for Global Development, Paris School of Economics, University of Paris-Dauphine, University of Oxford and University of Kent for useful comments.

Funding This study was funded by the Economic and Social Research Council (Grant number: RES-16725-0678).

\section{Compliance with ethical standards}

Conflict of interest The authors declare that they have no conflict of interest.

Open Access This article is distributed under the terms of the Creative Commons Attribution 4.0 International License (http://creativecommons.org/licenses/by/4.0/), which permits unrestricted use, distribution, and reproduction in any medium, provided you give appropriate credit to the original author(s) and the source, provide a link to the Creative Commons license, and indicate if changes were made.

\section{Appendix}

Table 13 Variables included in the composite index and respective weights

\begin{tabular}{|c|c|c|c|c|}
\hline Variable & Categories & Equal & PCA & MCA \\
\hline I am not happy on how & Agree & 0.20 & 0.2947 & 0.209 \\
\hline Morocco is administered & Disagree & & & -0.083 \\
\hline I do not think we should defend & Agree & 0.20 & 0.0966 & 0.200 \\
\hline the traditional lifestyle in Morocco & Disagree & & & -0.009 \\
\hline We need to make more effort & Agree & 0.20 & 0.5371 & 0.083 \\
\hline so that men and women are treated equally & Disagree & & & -0.693 \\
\hline We need to make more effort & Agree & 0.20 & 0.5571 & 0.062 \\
\hline so that everybody is treated equally & Disagree & & & -0.997 \\
\hline I think people should be more & Agree & 0.20 & 0.5523 & 0.707 \\
\hline involved in the decision-making process & Disagree & & & -0.086 \\
\hline
\end{tabular}

Data source: IIIMD, 2013 
Table 14 Robustness check-reference year for attractiveness

\begin{tabular}{|c|c|c|c|c|c|c|}
\hline & (1) & (2) & (3) & (4) & (5) & $(6)$ \\
\hline & Age $=25$ & Age $=26$ & Age $=27$ & Age $=28$ & Age $=29$ & Age $=30$ \\
\hline \multicolumn{7}{|c|}{ Political and social change } \\
\hline Return migration & $\begin{array}{l}0.102 \\
(3.01)^{* * * *}\end{array}$ & $\begin{array}{l}0.089 \\
(2.56)^{* *}\end{array}$ & $\begin{array}{l}0.109 \\
(2.72)^{* * *}\end{array}$ & $\begin{array}{l}0.113 \\
(2.91)^{* * *}\end{array}$ & $\begin{array}{l}0.117 \\
(3.01)^{* * *}\end{array}$ & $\begin{array}{l}0.113 \\
(3.09)^{* * *}\end{array}$ \\
\hline \multicolumn{7}{|c|}{ Probability of return migration } \\
\hline Shock & $\begin{array}{l}0.792 \\
(27.11)^{* * *}\end{array}$ & $\begin{array}{l}0.790 \\
(26.91)^{* * *}\end{array}$ & $\begin{array}{l}0.785 \\
(26.09) * * *\end{array}$ & $\begin{array}{l}0.784 \\
(25.90) * * *\end{array}$ & $\begin{array}{l}0.783 \\
(25.90)^{* * * *}\end{array}$ & $\begin{array}{l}0.783 \\
(25.89) * * *\end{array}$ \\
\hline \multicolumn{7}{|c|}{ Probability of emigration } \\
\hline Attractiveness & $\begin{array}{l}0.049 \\
(2.88)^{* * * *}\end{array}$ & $\begin{array}{l}0.044 \\
(2.40)^{* *}\end{array}$ & $\begin{array}{l}0.034 \\
(1.58)\end{array}$ & $\begin{array}{l}0.035 \\
(1.85)^{*}\end{array}$ & $\begin{array}{l}0.047 \\
(2.46)^{* *}\end{array}$ & $\begin{array}{l}0.045 \\
(2.29)^{* *}\end{array}$ \\
\hline sigma_1 & $\begin{array}{l}-1.959 \\
(41.11)^{* * *}\end{array}$ & $\begin{array}{l}-1.963 \\
(41.50) * * *\end{array}$ & $\begin{array}{l}-1.956 \\
(40.53)^{* * *}\end{array}$ & $\begin{array}{l}-1.954 \\
(40.61)^{* * *}\end{array}$ & $\begin{array}{l}-1.952 \\
(40.39)^{* * *}\end{array}$ & $\begin{array}{l}-1.954 \\
(40.92)^{* * *}\end{array}$ \\
\hline sigma_2 & $\begin{array}{l}-1.160 \\
(30.99)^{* * *}\end{array}$ & $\begin{array}{l}-1.160 \\
(31.00)^{* * *}\end{array}$ & $\begin{array}{l}-1.160 \\
(30.96)^{* * *}\end{array}$ & $\begin{array}{l}-1.160 \\
(30.96)^{* * *}\end{array}$ & $\begin{array}{l}-1.160 \\
(30.95)^{* * *}\end{array}$ & $\begin{array}{l}-1.160 \\
(30.96)^{* * *}\end{array}$ \\
\hline rho_12 & $\begin{array}{l}-0.218 \\
(3.00)^{* * *}\end{array}$ & $\begin{array}{l}-0.209 \\
(2.86)^{* * *}\end{array}$ & $\begin{array}{l}-0.224 \\
(3.00)^{* * *} *\end{array}$ & $\begin{array}{l}-0.228 \\
(3.07)^{* * *}\end{array}$ & $\begin{array}{l}-0.231 \\
(3.12)^{* * *}\end{array}$ & $\begin{array}{l}-0.230 \\
(3.10)^{* * * *}\end{array}$ \\
\hline rho_13 & $\begin{array}{l}-0.206 \\
(2.19)^{* *}\end{array}$ & $\begin{array}{l}-0.154 \\
(1.58)\end{array}$ & $\begin{array}{l}-0.229 \\
(1.90)^{*}\end{array}$ & $\begin{array}{l}-0.242 \\
(2.10)^{* *}\end{array}$ & $\begin{array}{l}-0.257 \\
(2.23)^{* *}\end{array}$ & $\begin{array}{l}-0.247 \\
(2.29)^{* *}\end{array}$ \\
\hline rho_23 & $\begin{array}{l}0.291 \\
(6.06)^{* * *}\end{array}$ & $\begin{array}{l}0.299 \\
(6.34)^{* * *}\end{array}$ & $\begin{array}{l}0.319 \\
(6.80)^{* * *}\end{array}$ & $\begin{array}{l}0.323 \\
(6.88)^{* * *}\end{array}$ & $\begin{array}{l}0.324 \\
(6.92)^{* * *}\end{array}$ & $\begin{array}{l}0.322 \\
(6.81)^{* * *}\end{array}$ \\
\hline$N$ & 441 & 441 & 441 & 441 & 441 & 441 \\
\hline
\end{tabular}

$* * *, * *$ and $*$ represent $1 \%, 5 \%$ and $10 \%$ significance levels, respectively. All specifications are weighted by the sampling weights provided in the dataset, with robust standard errors ( $t$ statistics in parentheses). The selection equations are based on full sample of 1524 observations. Data source: IIIMD 2013

Table 15 Robustness check - the direct impact of the historical attractiveness of foreign countries on the preference for political and social change of non-migrant households

\begin{tabular}{|c|c|c|c|c|c|c|}
\hline & (1) & (2) & (3) & (4) & (5) & (6) \\
\hline & PCA & MCA & Equal & PCA & MCA & Equal \\
\hline Attractiveness & $\begin{array}{r}-0.010 \\
(0.43)\end{array}$ & $\begin{array}{r}-0.005 \\
(0.18)\end{array}$ & $\begin{array}{r}-0.013 \\
(0.56)\end{array}$ & & & \\
\hline Attractiveness (FRA, CAN, LBY) & & & & $\begin{array}{r}-0.009 \\
(0.41)\end{array}$ & $\begin{array}{r}-0.004 \\
(0.16)\end{array}$ & $\begin{array}{r}-0.013 \\
(0.57)\end{array}$ \\
\hline Controls & Yes & Yes & Yes & Yes & Yes & Yes \\
\hline $\mathrm{R} 2$ & 0.14 & 0.13 & 0.16 & 0.14 & 0.13 & 0.16 \\
\hline$N$ & 243 & 243 & 243 & 243 & 243 & 243 \\
\hline
\end{tabular}

$* * *, * *$ and $*$ represent $1 \%, 5 \%$ and $10 \%$ significance levels, respectively. All specifications are weighted by the sampling weights provided in the dataset, with robust standard errors ( $t$ statistics in parentheses). The selection equations are based on full sample of 1524 observations. Data source: IIIMD 2013 


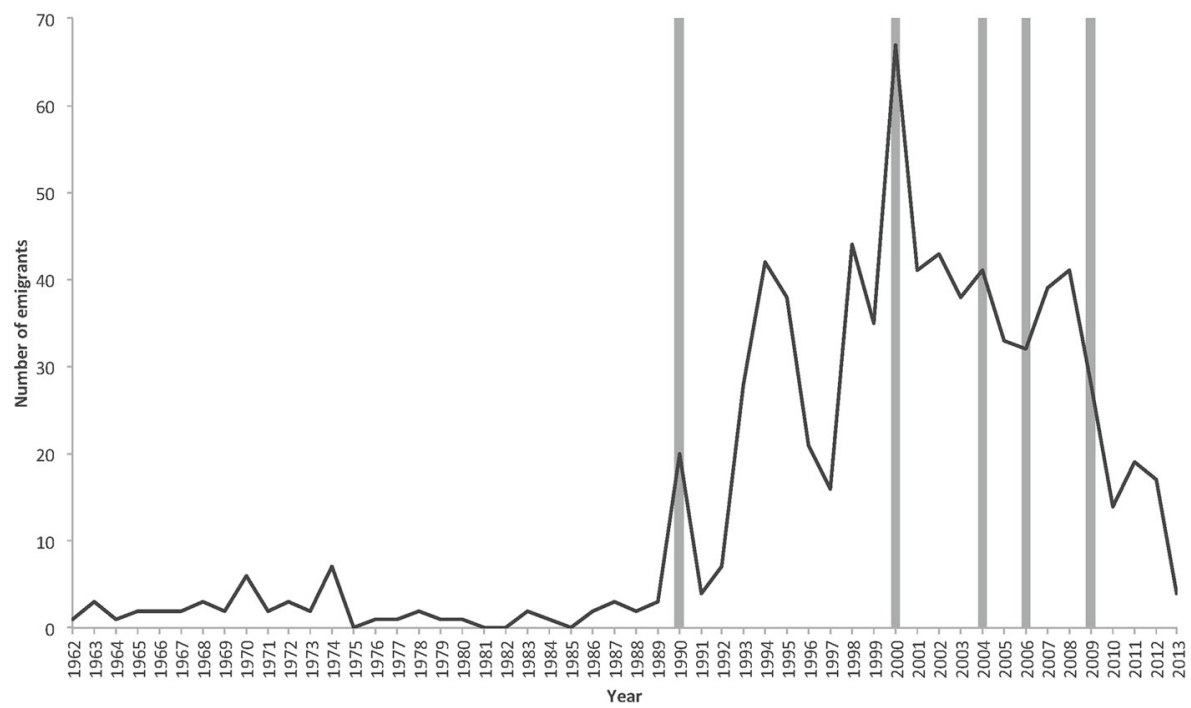

Fig. 1 Emigrants by year and shocks

Table 16 Return migration and the preference for change using a different exclusion restriction for the selection into emigration (attractiveness in FRA, CAN, LBY)

\begin{tabular}{llll}
\hline & $(1)$ & $(2)$ & $(3)$ \\
& PCA & MCA & Equal \\
\hline $\begin{array}{l}\text { Political and social change } \\
\text { Return migration }\end{array}$ & 0.093 & & \\
& $(2.72)^{* * *}$ & 0.072 & 0.079 \\
Probability of return migration & & $(2.23)^{* *}$ & $(2.59)^{* * *}$ \\
Shock & 0.792 & & 0.792 \\
Probability of emigration & $(27.14)^{* * *}$ & 0.792 & $(27.14)^{* * *}$ \\
Attractiveness (FRA, CAN, LBY) & & $(27.16)^{* * *}$ & 0.048 \\
& 0.048 & & $(2.83)^{* * *}$ \\
sigma_1 & $(2.81)^{* * *}$ & 0.049 & -1.160 \\
sigma_2 & -1.160 & $(2.85)^{* * *}$ & $(31.00)^{* * *}$ \\
rho_12 & $(30.99)^{* * *}$ & -1.160 & -0.981 \\
& -0.981 & $(30.99)^{* * *}$ & $(29.64)^{* * *}$ \\
rho_13 & $(29.63)^{* * *}$ & -0.981 & -0.171 \\
rho_23 & -0.212 & $(29.63)^{* * *}$ & $(2.38)^{* *}$ \\
& $(2.93)^{* * *}$ & -0.143 & -0.131 \\
& -0.170 & $(1.99)^{* *}$ & $(1.65)^{*}$
\end{tabular}

$* * *, * *$ and $*$ represent $1 \%, 5 \%$ and $10 \%$ significance levels, respectively. All specifications are weighted by the sampling weights provided in the dataset, with robust standard errors ( $t$ statistics in parentheses). The selection equations are based on full sample of 1524 observations. Data source: IIIMD 2013 
Table 17 Return migration and the preference for change using a different exclusion restriction for the selection into emigration (Moroccan GDP per capita growth)

\begin{tabular}{|c|c|c|c|}
\hline & (1) & $(2)$ & (3) \\
\hline & All & West & Non-West \\
\hline \multicolumn{4}{|l|}{ Political and social change } \\
\hline Return migration & $\begin{array}{l}0.092 \\
(2.69)^{* * *}\end{array}$ & $\begin{array}{l}0.074 \\
(2.69)^{* * *}\end{array}$ & $\begin{array}{l}-0.044 \\
(1.15)\end{array}$ \\
\hline \multicolumn{4}{|c|}{ Probability of return migration } \\
\hline Shock & $\begin{array}{l}0.794 \\
(27.45)^{* * *}\end{array}$ & $\begin{array}{l}0.798 \\
(28.36)^{* * *}\end{array}$ & $\begin{array}{l}0.800 \\
(28.40)^{* * * *}\end{array}$ \\
\hline \multicolumn{4}{|l|}{ Probability of emigration } \\
\hline Moroccan GDPpc growth & $\begin{array}{l}-0.009 \\
(1.90)^{*}\end{array}$ & $\begin{array}{l}-0.009 \\
(1.93)^{*}\end{array}$ & $\begin{array}{l}-0.009 \\
(1.97)^{* *}\end{array}$ \\
\hline sigma_1 & $\begin{array}{l}-1.160 \\
(31.01)^{* * *}\end{array}$ & $\begin{array}{l}-1.161 \\
(31.04)^{* * *}\end{array}$ & $\begin{array}{l}-1.161 \\
(31.05)^{* * *}\end{array}$ \\
\hline sigma_2 & $\begin{array}{l}-0.980 \\
(29.47)^{* * *}\end{array}$ & $\begin{array}{l}-0.980 \\
(29.51)^{* * *}\end{array}$ & $\begin{array}{l}-0.980 \\
(29.52)^{* * * *}\end{array}$ \\
\hline rho_12 & $\begin{array}{l}-0.210 \\
(2.91)^{* * *}\end{array}$ & $\begin{array}{l}-0.169 \\
(2.90)^{* * *}\end{array}$ & $\begin{array}{l}-0.069 \\
(1.46)\end{array}$ \\
\hline rho_13 & $\begin{array}{l}-0.165 \\
(1.72)^{*}\end{array}$ & $\begin{array}{l}-0.113 \\
(1.38)\end{array}$ & $\begin{array}{l}0.031 \\
(0.52)\end{array}$ \\
\hline rho_23 & $\begin{array}{l}0.280 \\
(6.21)^{* * * *}\end{array}$ & $\begin{array}{l}0.279 \\
(6.22)^{* * *}\end{array}$ & $\begin{array}{l}0.279 \\
(6.25)^{* * *}\end{array}$ \\
\hline$N$ & 441 & 441 & 441 \\
\hline
\end{tabular}

The exclusion restriction for emigration is GDP per capita growth rate in Morocco at the age of entry in the labour market. $* * *, * *$ and $*$ represent $1 \%, 5 \%$ and $10 \%$ significance levels, respectively. All specifications are weighted by the sampling weights provided in the dataset, with robust standard errors ( $t$ statistics in parentheses). The selection equations are based on full sample of 1524 observations. Data source: IIIMD 2013

Table 18 Return migration and the preference for change using a different exclusion restriction for the selection into return migration (conflicts)

$\begin{array}{lll}\text { (1) } & \begin{array}{l}(2) \\ \text { All }\end{array} & \begin{array}{l}(3) \\ \text { West }\end{array} \\ & & \\ 0.142 & 0.064 & -0.053 \\ (1.81)^{*} & (1.71)^{*} & (1.35) \\ & & \\ 0.669 & 0.681 & 0.663 \\ (10.12)^{* * *} & (9.92)^{* * *} & (9.84)^{* * *}\end{array}$


Table 18 (continued)

\begin{tabular}{llll}
\hline & $(1)$ & $(2)$ & $(3)$ \\
& All & West & Non-West \\
\hline $\begin{array}{l}\text { Probability of emigration } \\
\text { Attractiveness }\end{array}$ & 0.051 & & 0.051 \\
& $(2.92)^{* * *}$ & 0.051 & $(2.93)^{* * *}$ \\
& & $(2.92)^{* * *}$ & -1.068 \\
sigma_1 & -1.068 & & $(33.38)^{* * * *}$ \\
& $(33.38)^{* * *}$ & -1.068 & -0.974 \\
sigma_2 & -0.974 & $(33.38)^{* * *}$ & $(29.08)^{* * *}$ \\
rho_12 & $(29.07)^{* * *}$ & -0.974 & 0.021 \\
& -0.319 & $(29.08)^{* * *}$ & $(0.37)$ \\
rho_13 & $(1.83)^{*}$ & -0.124 & -0.043 \\
& -0.195 & $(1.38)$ & $(0.56)$ \\
rho_23 & $(1.68)^{*}$ & -0.111 & 0.348 \\
\hline
\end{tabular}

The exclusion restriction for return migration comes from Correlates of War. ***, ** and * represent $1 \%$, $5 \%$ and $10 \%$ significance levels, respectively. All specifications are weighted by the sampling weights provided in the dataset, with robust standard errors ( $t$ statistics in parentheses). The selection equations are based on full sample of 1524 observations. Data source: IIIMD 2013

Table 19 Selection into destination

(1)

$-0.043$

(1.11)

Happy to have lived abroad

Willingness to migrate again

Openness index
(3)

(4)

(5)

\begin{tabular}{|c|c|c|c|c|c|}
\hline \multirow[t]{2}{*}{ Migrated to improve lifestyle } & -0.043 & & & -0.033 & \\
\hline & $(1.11)$ & & & $(0.84)$ & \\
\hline \multirow[t]{2}{*}{ Happy to have lived abroad } & & -0.004 & & 0.010 & \\
\hline & & $(0.07)$ & & $(0.18)$ & \\
\hline \multirow[t]{2}{*}{ Willingness to migrate again } & & & -0.023 & -0.023 & \\
\hline & & & $(0.61)$ & $(0.62)$ & \\
\hline \multirow[t]{2}{*}{ Openness index } & & & & & -0.034 \\
\hline & & & & & $(0.53)$ \\
\hline $\mathrm{R} 2$ & 0.29 & 0.31 & 0.31 & 0.31 & 0.31 \\
\hline$N$ & 243 & 234 & 233 & 233 & 233 \\
\hline
\end{tabular}

$* * *, * *$ and $*$ represent $1 \%, 5 \%$ and $10 \%$ significance levels, respectively. All specifications are weighted by the sampling weights provided in the dataset, with robust standard errors ( $t$ statistics in parentheses). Dep. var. is a dummy being 1 if the returnee lived in the West, whilst it is 0 if he lived in a non-West country. Data source: IIIMD 2013 
Table 20 Having a returnee family member and the preference for political and social change

\begin{tabular}{|c|c|c|c|}
\hline & (1) & (2) & (3) \\
\hline & PCA & MCA & Equal \\
\hline \multicolumn{4}{|l|}{ Political and social change } \\
\hline \multirow[t]{2}{*}{ Household member of a returnee } & $0.110 * *$ & $0.091 *$ & $0.100 * *$ \\
\hline & $(0.048)$ & $(0.047)$ & $(0.043)$ \\
\hline \multicolumn{4}{|l|}{ Probability of return migration } \\
\hline \multirow[t]{2}{*}{ Shock } & $0.792 * * *$ & $0.792 * * *$ & $0.792 * * *$ \\
\hline & $(0.029)$ & $(0.029)$ & $(0.029)$ \\
\hline \multicolumn{4}{|l|}{ Probability of emigration } \\
\hline \multirow[t]{2}{*}{ Attractiveness } & $0.050 * * *$ & $0.050 * * *$ & $0.050 * * *$ \\
\hline & $(0.018)$ & $(0.018)$ & $(0.018)$ \\
\hline \multirow[t]{2}{*}{ sigma_1 } & $-1.936^{* * *}$ & $-1.852 * * *$ & $-1.983^{* * *}$ \\
\hline & $(0.061)$ & $(0.094)$ & $(0.067)$ \\
\hline \multirow[t]{2}{*}{ sigma_2 } & $-1.160 * * *$ & $-1.160 * * *$ & $-1.160 * * *$ \\
\hline & $(0.037)$ & $(0.037)$ & $(0.037)$ \\
\hline \multirow[t]{2}{*}{ rho_12 } & $-0.265^{* *}$ & $-0.217 *$ & $-0.232 * *$ \\
\hline & $(0.123)$ & $(0.118)$ & $(0.117)$ \\
\hline \multirow[t]{2}{*}{ rho_13 } & $-0.204^{*}$ & -0.131 & $-0.155^{*}$ \\
\hline & $(0.115)$ & (0.089) & $(0.094)$ \\
\hline \multirow[t]{2}{*}{ rho_23 } & $0.291 * * *$ & $0.291 * * *$ & $0.291 * * *$ \\
\hline & $(0.045)$ & $(0.045)$ & $(0.045)$ \\
\hline$N$ & 291 & 291 & 291 \\
\hline
\end{tabular}

$* * *, * *$ and $*$ represent $1 \%, 5 \%$ and $10 \%$ significance levels, respectively. All specifications are weighted by the sampling weights provided in the dataset, with robust standard errors ( $t$ statistics in parentheses). The selection equations are based on full sample of 1524 observations. Data source: IIIMD 2013

\section{References}

Acemoglu D, Robinson JA (2005) Economic origins of dictatorship and democracy. Cambridge University Press

Aidt TS, Franck R (2015) Democratization under the threat of revolution: evidence from the Great Reform Act of 1832. Econometrica 83(2):505-547

Asselin L-M (2002) Multidimensional poverty theory. Composite indicator of multidimensional poverty. Levis, Institut de Mathematique Gauss

Barro RJ (1999) Determinants of democracy. J Polit Econ 107(S6):S158-S183

Barsbai T, Rapoport H, Steinmayr A, Trebesch C (2017) The effect of labor migration on the diffusion of democracy: evidence from a former Soviet Republic. Am Econ J Appl Econ 9(3):36-69

Batista C, Vicente PC (2011) Do migrants improve governance at home? Evidence from a voting experiment. World Bank Econ Rev 25(1):77-104

Beine M, Sekkat K (2013) Skilled migration and the transfer of institutional norms. IZA Jof Migration 2(1):1-19

Beine M, Docquier F, Schiff M (2013) International migration, transfer of norms and home country fertility. Can J Econ 46(4):1406-1430 
Bertoli S, Marchetta F (2015) Bringing it all back home - return migration and fertility choices. World Dev 65:27-40

Borjas G, Bratsberg B (1996) Who leaves? The outmigration of the foreign-born. Rev Econ Stat 78(1):165-76

Brückner M, Ciccone A (2011) Rain and the democratic window of opportunity. Econometrica 79(3):923947

Campante FR, Chor D (2012) Why was the Arab world poised for revolution? Schooling, economic opportunities, and the Arab Spring. J Econ Perspect 26(2):167-187

Chaney E (2013) Revolt on the Nile: economic shocks, religion, and political power. Econometrica 81(5):2033-2053

Chauvet L, Mercier M (2014) Do return migrants transfer political norms to their origin country? Evidence from Mali. J Comp Econ 42(3):630-651

Chauvet L, Gubert F, Mesplé-Somps S (2016) Do migrants adopt new political attitudes from abroad? Evidence using a multi-sited exit-poll survey during the 2013 Malian elections. Comp Migr Stud $4(1): 19$

Chou MH, Baygert N (2007) The 2006 French immigration and integration law: Europeanisation or Nicolas Sarkozy's presidential keystone? COMPAS Working Paper No 45. COMPAS, Oxford

de Haas H (2014) Morocco: profile. Migration Policy Institute, Washington

de Haas H, Fokkema T (2010) Intra-household conflicts in migration decisionmaking: return and pendulum migration in Morocco. Popul Develop Rev 36(3):541-561

Diabate I, Mesplé-Somps S (2019) Female genital mutilation and migration in Mali. Do return migrants transfer social norms? Journal of Population Economics, forthcoming

Docquier F, Lodigiani E, Rapoport H, Schiff M (2016) Emigration and democracy. J Dev Econ 120:209223

Enikolopov R, Petrova M, Zhuravskaya E (2011) Media and political persuasion: evidence from Russia. Am Econ Rev 101(7):3253-3285

Filmer D, Pritchett LH (2001) Estimating wealth effects without expenditure data - or tears: an application to educational enrollments in states of India. Demography 38(1):115-132

Giuliano P, Spilimbergo A (2013) Growing up in a recession. Rev Econ Stud 81(2):787-817

Gubert F, Nordman CJ (2011) Return migration and small enterprise development in the Maghreb. In: Diaspora for development in Africa. World Bank, Washington, DC

Hamdouch B, Mghari M (2014) Impact de la migration internationale sur le developpement au Maroc: Resultats de l'enquete de 2013. IOM and MCMREAM

Hamdouch B, Wahba J (2015) Return migration and entrepreneurship in Morocco. Middle East Develop J 7(2):129-148

Höckel LS, Silva MS, Stöhr T et al (2018) Can parental migration reduce petty corruption in education? World Bank Econ Rev 32(1):109-126

Ivlevs A, King RM (2017) Does emigration reduce corruption? Public Choice 171(3-4):389-408

Karakoc E, Köse T, Özcan M (2017) Emigration and the diffusion of political Salafism: religious remittances and support for Salafi parties in Egypt during the Arab Spring. Party Polit 23(6):731-745

Khachani M (2012) Migrations et competences au Maroc Projet de Rapport ETF, AMERM, ENP-S-CSP Working Paper

Migration Policy Centre (2013) MPC - Migration Profile: Libya. Fiesole, European University Institute

Nikolova M, Roman M, Zimmermann KF (2017) Left behind but doing good? Civic engagement in two post-socialist countries. J Comp Econ 45(3):658-684

Özden Ç., Parsons CR, Schiff M, Walmsley TL (2011) Where on earth is everybody? The evolution of global bilateral migration 1960-2000. World Bank Econ Rev 25(1):12-56

Pfutze T (2012) Does migration promote democratization? Evidence from the Mexican transition. J Comp Econ 40(2):159-175

Roodman D (2011) Estimating fully observed recursive mixed-process models with CMP. Stata J 11(2):159-206

Spilimbergo A (2009) Democracy and foreign education. Am Econ Rev, 528-543

Tuccio M, Wahba J (2018) Return migration and the transfer of gender norms: evidence from the Middle East. J Comp Econ 46(4):1006-1029

Wahba J (2015) Selection, selection, selection: the impact of return migration. J Popul Econ 28:535-563

Publisher's note Springer Nature remains neutral with regard to jurisdictional claims in published maps and institutional affiliations. 